\title{
PENGEMBANGAN LEMBAR KERJA SISWA (LKS) BERBASIS PENEMUAN TERBIMBING PADA MATERI BANGUN RUANG SISI LENGKUNG SISWA KELAS IX DI SMPN 31 KAB. TEBO
}

\author{
Duwi Riskawati ${ }^{1}$, Buyung $^{2}$, Ayu Yarmayani ${ }^{3}$ \\ Program Studi Pendidikan Matematika, FKIP, Universitas Batanghari ${ }^{1,2,3}$ \\ Jl. Slamet Riyadi No. 1 Jambi \\ e-mail : -
}

\begin{abstract}
ABSTRAK
Penelitian ini adalah penelitian pengembangan (R\&D). Penelitian ini bertujuan untuk menghasilkan produk dalam bentuk Lembar Kerja Siswa Matematika berdasarkan penemuan terbimbing pada bangunan sisi ruang melengkung dilihat dari kriteria, kepraktisan, efektifitas dan validitas. Penelitian ini mengacu pada model pengembangan ADDIE yang meliputi lima tahap: analisis, desain, pengembangan, implementasi dan evaluasi. Subjek penelitian ini adalah siswa kelas IX SMP N 31 Kab. Tebo. Instrumen yang digunakan dalam penelitian ini adalah (a) lembar validasi untuk ahli materi, ahli media dan ahli desain untuk menentukan validitas Lembar Kerja Siswa, (b) kuesioner respon siswa untuk menentukan kepraktisan Lembar Kerja Siswa dan (c) pra -test dan post-test berfungsi untuk menentukan efektifitas Lembar Kerja Siswa. Hasil penelitian menunjukkan bahwa Lembar Kerja Siswa Berbasis Siswa dipandu di sisi bangunan ruang melengkung siswa Kelas XI termasuk dalam kategori baik dilihat dari validasi dari pakar yang mendapat skor rata-rata 4,2 , termasuk dalam kategori praktis dilihat dari angket respon siswa yang memperoleh skor rata-rata 4,4 dan diklasifikasikan secara efektif dilihat dari hasil perhitungan selisih antara tes dan post-test dengan nilai $t$ hitung adalah 15,4 dan nilai t tabel adalah 2,03. Dalam hal ini, $\mathrm{t}$ hitung $>\mathrm{t}$ tabel maka Ho diterima.
\end{abstract}

\section{Kata kunci:}

Pengembangan, Lembar Kerja Siswa, Penemuan Terbimbing.

\begin{abstract}
This thesis was a research and development $(R \& D)$. This research aimed to produce products in the form of Mathematics Student Worksheet based on the guided discovery on the space curved side building seen from the criteria, practicality, effectiveness and validity. This research referred to the model of ADDIE development which includes five stages: analysis, design, development, implementation and evaluation. The subject of this research was the students of class IX SMP N 31 $K a b . T e b o$. The instruments used in this research were (a) validation sheet for the material expert, media expert and design expert to determine the validity of Student Worksheet, (b) questionnaire of student response to determine the practicality of the Student Worksheet and (c) pre-test and post-test function to determine the effectiveness of Student Worksheet.The results of the research showed that the Student-Based Student Worksheet were guided in the space curved side building of the Class XI students belonging to the good category seen from the validation of the expert who got the average score of 4.2, belonging to the practical category seen from the questionnaire of the response of the students who obtained the average score of 4.4 and classified as effectively seen from the results of the calculation of the difference between pre- test and post-test with the value of $t_{\text {arithmetic was }} 15.4$ and the value of $t$ table was 2.03. In this case, $t_{\text {arithmetic }}>t_{\text {table }}$ then Horeceived.
\end{abstract}

Keywords :

Development, Student Worksheet, Guided Discovery.

\section{PENDAHULUAN}

Matematika merupakan ilmu yang mendasari perkembangan teknologi dan mempunyai peran penting dalam berbagai disiplin ilmu. Sebagai ilmu dasar, matematika memegang peran penting dalam menumbuhkembangkan daya nalar, cara berfikir logis, sistematis dan kritis. Selain itu, matematika juga memiliki banyak kegunaan dalam setiap aspek kehidupan manusia, seperti halnya dalam hal jual beli, hutang piutang dan lain sebagainya. 


\section{$\pi$ (Phi)}

Mengingat adanya hal yang sedemikian matematika juga sering dikatakan sebagai induk dari segala ilmu. Sehingga, pembelajaran matematika perlu sekali diberikan kepada semua peserta didik mulai sekolah dasar untuk membekali peserta didik tersebut menuju persaingan yang global. Pembekalan ilmu kepada peserta didik dilakukan dengan cara memberikan sebuah pelajaran melalui proses pembelajaran.

Proses pembelajaran tidak akan terlepas dengan yang namanya bahan ajar. Bahan ajar merupakan segala bahan (baik informasi, alat, maupun teks) yang disusun secara sistematis, yang menampilkan kompetensi yang dikuasai peserta didik dan digunakan dalam proses pembelajaran dengan tujuan perencanaan implementasi pembelajaran (Prastowo, 2015). Menurut Panne (Belawati, 2011) Bahan ajar adalah bahan-bahan atau materi pelajaran yang disusun secara sistematis yang digunakan guru dan siswa dalam proses pembelajaran.Dengan melihat adanya hal yang sedemikian bahan ajar memiliki peran yang sangat penting dalam proses pembelajaran, karena tersedianya bahan ajar diharapkan dapat membantu meningkatkan efektifitas dan dan kelancaran dalam proses pembelajaran sehingga tujuan pembelajaran dapat tercapai secara optimal. Ada banyak sekali jenis bahan ajar, salah satunya adalah Lembar Kerja Siswa (LKS).

Menurut Prastowo (2015) Lembar Kerja Siswa (LKS) merupakan suatu bahan ajar cetak berupa lembar-lembar kertas yang berisi materi, ringkasan, dan petunjukpetunjuk pelaksanaan tugas pembelajaran yang harus dikerjakan oleh peserta didik, yang mengacu pada kompetensi dasar yang harus dicapai. Sedangkan menurut Trianto (2007), Lembar Kerja Siswa (LKS) adalah panduan siswa yang digunakan untuk melakukan kegiatan penyelidikan atau pemecahan masalah. Keberadaan LKS sendiri seharusnya bisa memberikan peluang yang lebih besar untuk memperoleh prestasi belajar yang baik dan menjadikan siswa mengungkapkan kemampuan dan keterampilan untuk berbuat sendiri dalam mengembangkan proses berfikirnya. Namun tidak semua LKS dapat menjadikan hal yang sedemikian menjadi terwujud, karena LKS pada umumnya memiliki tampilan yang kurang menarik dan hanya berisi ringkasan materi serta latihan soal-soal saja. Kondisi yang sedemikian menjadikan siswa malas untuk mempelajari LKS yang ada, kurang memberikan pengalaman belajar bagi siswa dan tidak mendorong pengembangan kemampuan berfikir siswa, sehingga diperlukan pengembangan LKS yang mendukung. LKS yang dikembangkan diharapkan dapat melatih kemandirian siswa untuk menemukan, menerapkan, dan memperdalam konsep matematika.

Metode penemuan merupakan metode pembelajaran yang berpusat pada siswa dan melatih kemandirian siswa. Menurut Markaban (2006) metode penemuan yang dipandu oleh guru ini pertama kali dikembangkan oleh Plato dalam suatu dialog antara Scorates dan seorang anak, sehingga sering disebut dengan metode Scorates. Dalam metode penemuan terbimbing, guru berperan sebagai fasilitator yang membimbing siswa melalui pertanyaan-pertanyaan yang mengarahkan siswa untuk menghubungkan pengetahuan yang lalu dengan pengetahuan yang sedang di peroleh. Para siswa diarahkan untuk dapat membuat sebuah hipotesa serta menarik sebuah kesimpulan.

Berdasarkan permasalahan tersebut, perlu sekali dikembangkan bahan ajar berupa Lembar Kerja Siswa (LKS) yang berbasis penemuan terbimbing pada materi bangun ruang sisi lengkung mengingat materi tersebut cukup sulit dipahami oleh siswa dan bangun ruang sisi lengkung cocok digunakan untuk mengembangkan LKS dengan basis penemuan terbimbing. LKS berbasis penemuan terbimbing dapat 


\section{$\pi$ (Phi)}

membantu siswa dalam proses pembelajaran untuk dapat mengolah dan mengkontruksi kemampuan mereka sendiri dalam memecahkan masalah secara mandiri, mengembangkan keterampilanketerampilan berfikir, serta menganalisis dan memanipulasi informasi yang telah mereka peroleh dari proses pembelajaran sehingga ilmu yang diperoleh dapat bertahan lama. Dalam kondisi yang sedemikian peran guru adalah dengan cara membimbing mereka ke arah yang tepat.

\section{METODE PENELITIAN}

Jenis penelitian ini adalah penelitian pegembangan (Research \& Development). Produk yang dihasilkan dari penelitian ini adalah Lembar Kerja Siswa (LKS) berbasis penemuan terbimbing pada materi bangun ruang sisi lengkung untuk siswa kelas IX yang valid, praktis dan efektif. Model pengembangan yang digunakan adalah model ADDIE. Prosedur yang dilakukan dalam penelitian yaitu terdiri dari 5 tahap yaitu: (a) tahap analisis (analysis); (b) desain (design); (c) pengembangan (develompment); (d) Implementasi (implementation); dan (e) penilaian (evaluation).

Adapun data yang diperoleh dalam penelitian ini ada 3 yaitu data validitas diperoleh dari angket hasil validasi oleh 3 validator,data praktikalitas LKS diperoleh dari angket siswa dan data efektifitas diperoleh dari hasil belajar siswa setelah melakukan proses pembelajaran menggunakan LKS. Pada penelitian ini data yang diperoleh dianalisis dengan dua teknis analisis, yaitu analisis kualitatif dan analisis kuantitatif. Data kualitatif diperoleh dari komentar dan masukan dari ahli dan siswa sedangkan data kuantitatif diperoleh dari hasil penilaian melalui angket tentang produk LKS yang dikembangkan berupa skor tanggapan validator dan siswa tentang LKS yang dikembangkan. Data kualitatif diperoleh dari tanggapan para ahli dan siswa. Analisis Keefektifan digunakan untuk menganalisis data hasil belajar yang diperoleh dari hasil pre-test dan post-test yang diberikan yang berpatokan pada selisih dari nilai pre-test dan post-test.

\section{HASIL DAN PEMBAHASAN}

Pengembangan Lembar Kerja Siswa (LKS) berbasis penemuan terbimbing pada materi bangun ruang sisi lengkung siswa kelas IX SMP N 31 Kab. Tebo menggunakan model ADDIE. Model pengembangan tersebut meliputi lima tahap, yaitu tahap analisis (analysis), tahap perancangan (design), tahap pengembangan (development), tahap implementasi (implementation), dan tahap evaluasi (evaluation).

Tahap analisis (analysis) meliputi analisis kurikulum dan analisis kondisi siswa. Pada tahap ini peneliti mencari informasi tentang kurikulum yang dipakai di sekolahh sekaligus mencari tahu permasalahan apa yang menyebabkan rendahnya hasil belajar siswa di SMP N 31 Kab. Tebo dengan mewawancarai salah satu guru mata pelajaran matematika di kelas IX bernama Yelsa Apri Murti. Menurut beliau, rendahnya hasil belajar matematika dikarenakan masih banyak siswa/i yang tidak menyukai pelajaran matematika, hal ini bisa disebabkan oleh beberapa faktor mulai dari pelajarannya yang sulit dimengerti, banyak rumus-rumus, tidak menarik, dan ada juga yang tidak menyukai pelajaran matematika dikarenakan tidak menyukai guru yang mengajarnya. Dengan mempertimbangkan hasil analisis karakteristik siswa tersebut peneliti memutuskan untuk mengembangkan Lembar Kerja Siswa (LKS) berbasis penemuan terbimbing pada materi bangun ruang sisi lengkung siswa kelas IX SMP N 31 Kab. Tebo. Pengembangan ini dikarenakan LKS yang akan dibuat dapat membantu siswa dalam menemukan rumus-rumus sehingga belajar matematika terkhusus bangun ruang sisi lengkung menjadi lebih menarik. 


\section{$\pi$ (Phi)}

Setelah tahap analisis selesai, tahap selanjutnya yaitu tahap perancangan (design). Kegiatan yang dilakukan pada tahap design meliputi persiapan pembuatan produk, penyusunan kerangka dasar LKS dan penyusunan instrumen penilaian dengan dibantu oleh informasi yang dari berbagai sumber yang dapat dipercaya. Instrumen penelitian yang akan digunakan meliputi instrumen penilaian LKS oleh ahli materi, ahli media, ahli desain, angket respon siswa dan tes hasil belajar siswa. Instrumen penilaian LKS oleh para ahli disusun guna memperoleh penilaian LKS ditinjau dari segi kevalidannya. Setelah penyusunan instrumen penelitian selesai, selanjutnya instrumen-instrumen tersebut diperlihatkan kepada dosen pembimbing. Selanjutnya, instrumen yang telah disetujui oleh dosen pembimbing digunakan untuk pengambilan data.

Tahap pengembangan (development) merupakan pelaksanaan dari rencana yang telah disusun pada tahap perancangan (design). Kegiatan yang dilakukan pada tahap pengembangan yaitu membuat LKS matematika berbasis penemuan terbimbing sesuai dengan struktur yang telah dirancang seperti (1) menyusun LKS sesuai dengan Standar Kompetensi (SK), Kompetensi Dasar (KD), Indikator dan tujuan pembelajaran pada materi faktorisasi suku aljabar, (2) menyusun materi, memperhatikan struktur LKS.

Penilaian LKS oleh ahli materi mencakup aspek kecermatan isi, ketepatan cakupan isi, ketercernaan, penggunaan bahasa dan mendorong keingintahuan. Dari pembahasan di atas dilihat dari aspek kecermatan isi, aspek katepatan cakupan isi, ketercernaan dan aspek medorong keingintahuan, LKS memperoleh skor dengan rata-rata 4 sehingga termasuk dalam kategori baik atau jika dihitung ke dalam persentase LKS memiliki tingkat keakuratan sebesar $80 \%$ sehingga termasuk dalam kategori valid. Dilihat dari aspek mendorong keingintahuan, LKS memperoleh skor dengan rata-rata 4,25 sehingga termasuk dalam kategori sangat baik atau jika dihitung ke dalam persentase LKS memiliki tingkat keakuratan sebesar $85 \%$ sehingga termasuk dalam kategori sangat valid. Berdasarkan penilaian oleh ahli materi, LKS yang dikembangkan memperoleh skor rata-rata 4,4 sehingga termasuk kategori sangat baik atau jika dihitung ke dalam persentase, LKS memiliki tingkat keakuratan sebesar 88,3\% sehingga termasuk dalam kategori sangat valid untuk digunakan sebagai perangkat pembelajaran.

Penilaian LKS oleh ahli media mencakup aspek desain tampilan, mutu gambar, penggunaan font dan layout (tata letak). Dilihat dari aspek desain tampilan, LKS memperoleh skor dengan rata-rata 4,4 sehingga termasuk dalam kategori sangat baik atau jika dihitung ke dalam persentase LKS memiliki tingkat keakuratan sebesar $88 \%$ sehingga termasuk dalam kategori sangat valid. Dilihat dari aspek mutu gambar, LKS memperoleh skor dengan rata-rata 4,3 sehingga termasuk dalam kategori sangat baik atau jika dihitung ke dalam persentase LKS memiliki tingkat keakuratan sebesar 86,6\% sehingga termasuk dalam kategori sangat valid. Dilihat dari aspek penggunaan font dan layout (tata letak), LKS memperoleh skor dengan rata-rata 4,5 sehingga termasuk dalam kategori sangat baik atau jika dihitung ke dalam persentase LKS memiliki tingkat keakuratan sebesar $90 \%$ sehingga termasuk dalam kategori sangat valid. Berdasarkan penilaian oleh ahli media, LKS yang dikembangkan memperoleh skor rata-rata 4,4 sehingga termasuk kategori sangat baik. atau jika dihitung ke dalam persentase, LKS mendapatkan nilai 88,3\% sehingga termasuk dalam kategori sangat valid untuk digunakan sebagai perangkat pembelajaran.

Penilaian LKS oleh ahli desain mencakup aspek kelengkapan komponen dan LKS berbasisi penemuan terbimbing. 


\section{$\pi$ (Phi)}

Dilihat dari aspek kelengkapan komponen, LKS memperoleh skor dengan rata- rata 3.33 sehingga termasuk dalam kategori cukup baik atau jika dihitung ke dalam persentase, LKS mendapatkan nilai $66,66 \%$ sehingga termasuk dalam kategori valid. Dilihat dari LKS berbasis penemuan terbimbing, LKS memperoleh skor dengan rata-rata 3,66 sehingga termasuk dalam kategori baik atau jika dihitung ke dalam persentase, LKS mendapatkan nilai sebesar $73,33 \%$ sehingga termasuk dalam kategori valid.

Berdasarkan penilaian oleh ahli desain, LKS yang dikembanngkan memperoleh skor rata-rata 3,55 sehingga termasuk kategori baik baik atau jika dihitung ke dalam persentase, LKS mendapatkan nilai sebesar $71,11 \%$ sehingga termasuk dalam kategori valid untuk digunakan sebagai perangkat pembelajaran.

Dari kegiatan validasi tersebut dapat disimpulkan bahwa LKS berbasis penemuan terbimbing layak untuk di uji cobakan sesuai komentar dan saran yang diperoleh dari para ahli.

Tahap selanjutnya adalah tahap implementasi (implementation). Pada tahap ini dilakukan uji coba terhadap LKS.Terdapat 2 uji coba yaitu uji coba perorangan yang terdiri dari 3 orang siswa non subjek, uji coba kelompok kecil yang terdiri dari 6 orang siswa dengan kemampuan belajar tinggi, sedang dan rendah. Pemilihan siswa pada uji coba perorangan dan kelompok kecil dibantu oleh guru matematika yang mengajar di sekolah tersebut tepatnya guru matematika kelas IX. Tahap selanjutnya peneliti melakukan uji coba lapangan pada siswa kelas IXA SMPN 31 Kab. Tebo dan memperoleh tanggapan siswa terhadap LKS yang dikembangkan dengan skor rata-rata sebesar 4,4 yang termasuk dalam kategori sangat baik.dengan persentase sebesar $88,8 \%$ dengan kategori sangat praktis.

Tahap paling akhir dalam pengembangan ini adalah tahap evaluasi (evaluation). Pada tahap evlauasi LKS diperbaiki sesuai saran dari para ahli, angket respon siswa, dan catatan selama uji coba sehingga terciptalah LKS berbasis penemuan terbimbing pada materi bangun ruang sisi lengkung siswa kelas IX yang valid dan praktis. Selain kevalidan dan kepraktisan, keefektifan LKS berbasis penemuan terbimbing dibuktikan berdasarkan perhitungan selisih hasil tes kemampuan awal (pre-test) dan tes kemapuan akhir (pos-test) terhadap kelas subjek yang berjumlah 32 orang siswa. Soal yang digunakan untuk tes merupakan soal yang sama dengan dilihat oleh dua orang ahli materi dalam hal ini satu orang dan satu orang guru matematika dari aspek kriteria isi dan kriteria kebahasaan. Berdasarkan perhitungan selisih hasil tes diperoleh thitung sebesar 15,4 dan tabel sebesar 2,03. Karena $t_{\text {hitung }}>t_{\text {tabel }}$ maka Ho di terima dan disimpulkan bahwa LKS berbasis penemuan terbimbing dikategorikan efektif. Dengan demikian LKS berbasis penemuan terbimbing pada materi bangun ruang sisi lengkung dikategorikan valid, praktis dan efektif.

\section{SIMPULAN DAN SARAN}

Berdasarkan uraian pada hasil penelitian dan pembahasan penulis dapat menyimpulkan bahwa Pengembangan Lembar Kerja Siswa (LKS) berbasis penemuan terbimbing pada materi bangun ruang sisi lengkung siswa kelas IX di SMP N 31 Kab. Tebo dilakukan melalui lima tahap pengembangan menurut Model Pengembangan ADDIE. Tahap pengembangan menggunkan model ADDIE diawali dengan tahap analisis (Analysis), tahap perancangan (Design), tahap pengembangan (Development), tahap implementasi (Implementation) dan yang tahap evaluasi (Evaluation) yang merupakan tahap paling akhir. Adapun kualitas Lembar Kerja Siswa (LKS) berbasis penemuan terbimbing pada materi 


\section{$\pi$ (Phi)}

bangun ruang sisi lengkung antara lain sebagai berikut.

a. Dilihat dari aspek kevalidan

Berdasarkan penilaian oleh ahli materi, LKS yang dikembangkan memperoleh skor rata-rata 4,4 sehingga termasuk kategori sangat baik. atau jika dihitung ke dalam persentase, LKS mendapatkan nilai $88,3 \%$ sehingga termasuk dalam kategori sangat valid untuk digunakan sebagai perangkat pembelajaran.

Berdasarkan penilaian oleh ahli media, LKS yang dikembangkan memperoleh skor rata-rata 4,4 sehingga termasuk kategori sangat baik. atau jika dihitung ke dalam persentase, LKS mendapatkan nilai $88,3 \%$ sehingga termasuk dalam kategori sangat valid untuk digunakan sebagai perangkat pembelajaran.

Berdasarkan penilaian oleh ahli desain, LKS yang dikembanngkan memperoleh skor rata-rata 3,55 sehingga termasuk kategori baik baik atau jika dihitung ke dalam persentase, LKS mendapatkan nilai sebesar $71,11 \%$ sehingga termasuk dalam kategori valid untuk digunakan sebagai perangkat pembelajaran.

b. Dilihat dari aspek kepraktisan

Dilihat dari aspek kepraktisan, LKS yang dikembangkan memperoleh kriteria praktis. Hal tersebut terlihat dari angket respon siswa memperoleh skor rata-rata sebesar 4,4 yang termasuk dalam kategori sangat baik.dengan persentase sebesar $88,8 \%$ dengan kategori sangat praktis.

c. Dilihat dari aspek Keefektifan

Dilihat dari aspek keefektifan, LKS yang dikembangkan memperoleh kriteria efektif. Hal tersebut terlihat dari perhitungan selisih hasil tes diperoleh thitung sebesar 15,4 dan ttabel sebesar 2,03. Dalam ini, $t_{\text {hitung }}$ lebih besar dari $\mathrm{t}_{\text {tabel }}$ maka Ho di terima.

\section{DAFTAR PUSTAKA}

Annurahman. 2014. Belajar dan Pembelajaran. Bandung: Alfabeta
Belawati, dkk.2007. Pengembangan Bahan Ajar. Jakarta: Universitas Terbuka.

Branch, Robert. 2009. Instructional Design: The ADDIE Approach. Springer. USA.

Djaali dan mujono, P. Pengaruh dalam Bidang Pendidikan. Jakarta: PT Grasindo.

Erman, dkk. 2003. Strategi Pembelajaran Matematika Kontemporer. Bandung: Jca Common Text Book.

Hamalik.Oemar. 2013. Kurikulum dan Pembelajaran. Jakarta: Bumi Aksara.

Lestari, Ika. 2012. Pengembangan bahan ajar Berbasis Kompetesi Sesuai Dengan Kurikulum Tingkat Satuan. Padang: Kademia

Prastowo, Andi. 2011. Penduan Membuat Bahan Ajar Inovatif. Yogyakarta: Diva Pres.

Slameto. 2010. Belajar dan Faktor-Faktor yang Mempengaruhinya. Jakarta: rineka Cipta.

Sudjana. 2005. Metoda Statistika. Bandung: Tarsito.

Sugiyono. 2013.Metode Penelitian Pendidikan Pendekatan Kuantitatif, Kualitatif, dan $R$ \& D. Bandung: Alfabeta

Supardi.2014. Aplikasi Statistikadalam Penelitian Konsep Statistika yang Lebih Komprehensif.Jakarta: Change Puplication.

Susanto, Ahmad. 2013. Teori Belajar dan Pembelajaran Di Sekolah Dasar. Jakarta: Kencana.

Tegeh, dkk. 2014. Model Penelitian Pengembangan. Yogyakarta: Graha Ilmu.

Trianto. 2007. Model Pembelajaran Terpadu Dalam Terori dan Praktek. Surabaya: Prestasi Pustaka Publisher. 